\title{
Meningioma of the Pineal Region - Differential Radiologic Aspects of Pineal Region Tumors Based on a Clinical Case
}

\section{Meningioma da região da pineal - aspectos radiológicos diferenciais dos tumores da região pineal baseado em um caso clinico}

\author{
Tiago Marques Avelar ${ }^{1}$ Aline Lariessy Campos Paiva ${ }^{1}$ Márcio Alexandre Teixeira da Costa ${ }^{1}$ \\ Guilherme Brasileiro de Aguiar ${ }^{1}$ João Luiz Vitorino ${ }^{1}$ José Carlos Esteves Veiga ${ }^{1}$ \\ ${ }^{1}$ Faculdade de Ciências Médicas da Santa Casa de São Paulo, São \\ Paulo, SP, Brazil \\ Arq Bras Neurocir 2018;37:145-147. \\ Address for correspondence Tiago Marques Avelar, MD, Faculdade de \\ Ciências Médicas da Santa Casa de São Paulo, Rua Doutor Cesário \\ Motta Júnior, 61 - Vila Buarque, São Paulo, SP, 01221-020, Brazil \\ (e-mail: avelar.tm@gmail.com).
}

\section{Abstract \\ Keywords \\ - meningioma \\ - pineal gland \\ - brain neoplasms}

\section{Resumo}

\section{Palavras-chave}

- meningioma

- glândula pineal

- neoplasias encefálicas
Pineal region tumors are uncommon among neoplasm of the central nervous system, with this region being the most heterogeneous in terms of histological types. Meningiomas are rarer still, but can be found at this site, with origins in either the velum interpositum or falcotentorial junction. Neuroimaging exams can distinguish malignant from benign lesions besides helping to define the origin of the lesion as the pineal parenchymal or surrounding structures. We report the case of a woman with a pineal region tumor in which differential diagnoses included meningioma and germinoma, with confirmation of the former based on radiological characteristics and histopathology. In addition, a brief review of differential diagnoses and approaches for cases of lesions in this region is provided.

Os tumores da região da pineal apresentam uma baixa frequência entre as neoplasias do sistema nervoso central, sendo esta região a mais heterogênea em termos de tipos histológicos possíveis. Meningiomas são lesões ainda mais raras, porém possíveis de advirem desta localização, sejam originados do velum interpositum ou da junção falcotentorial. Os exames de neuroimagem permitem distinguir lesões malignas de benignas além de auxiliar na definição entre origem do parênquima pineal ou de estruturas adjacentes. Apresentamos o caso de uma mulher adulta com uma neoplasia da região da pineal cujos diagnósticos diferenciais incluíram meningioma e germinoma, evidenciando-se pelas características radiológicas e resultados histopatológicos tratar-se do primeiro. Além disso, fazemos uma breve revisão a respeito dos diagnósticos diferencias e condutas frente a uma lesão desta região. received

August 15, 2017

accepted

April 3, 2018

published online

July 12, 2018
DOI https://doi.org/

10.1055/s-0038-1651527. ISSN 0103-5355.
Copyright $(2018$ by Thieme Revinter

Publicações Ltda, Rio de Janeiro, Brazil
License terms

(c) (1) $\ominus$ (\$) 


\section{Introduction}

Tumors of the pineal gland are uncommon, accounting for only 0.4 to $1 \%$ of all intracranial tumors in adults. Other neoplasms with origin in the pineal region, whose incidence lies in the 0.4 to $8 \%$ range depending on the author, are often addressed together in the literature. ${ }^{1}$ The most common histological types of pineal tumors are those derived from germinative cells and pineal parenchymal tumors, representing $89 \%$ of the lesions in this region. ${ }^{1}$ Meningiomas of the pineal region are rare entities and make up 2 to $8 \%$ of all tumors found in this area. ${ }^{2}$

The pineal region is the most heterogeneous in the central nervous system in terms of histological types of tumor, ${ }^{3}$ and imaging exams can help to confirm the diagnosis besides helping to define the approach and plan of operation. ${ }^{4}$ Germinomas can secrete markers such as $\beta$ human chorionic gonadotropin ( $\beta$-HCG) and $\alpha$-fetoprotein $(\alpha-\mathrm{FP})$, whose presence can preclude the need for surgical biopsy. Cases in which these markers are absent require histological confirmation via biopsy or lesion removal. ${ }^{5}$ Surgical removal is the treatment of choice for meningiomas, and is regarded as the definitive treatment. ${ }^{6}$

The objective of this article was to report the case of a meningioma in the pineal region and provide a brief review of its differential diagnoses and therapeutic management.

\section{Case Report}

A 43-year-old female teacher presented with a 1-year history of headache. Initial physical exam revealed no visual changes, gait problems, motor deficits or cerebellar signs. Brain magnetic resonance imaging (MRI) was then performed, disclosing an expansive lesion in the pineal gland region, with initially suspected differential diagnoses of meningioma and germinoma. The patient was submitted to initial conservative treatment. However, the repeat MRI after 6 months (- Fig. 1) revealed lesion growth concomitant with worsening headache. Given the strong suspicion of meningioma based on the MRI characteristics, surgical treatment of the lesion was elected.

Occipital craniotomy with transtentorial access was employed to resect the lesion, since this route permits an excellent view both above and below the tentorial notch. The frozen section biopsy revealed meningioma, subsequently confirmed by histopathologic analysis and immunohistochemistry, which revealed a World Health Organization (WHO) grade I meningothelial meningioma. The follow-up MRI exam showed complete resection of the lesion. The patient evolved without neurological deficits and was headache free at 1-year follow-up.

\section{Discussion}

Pineal meningiomas can be classified into two distinct entities: falcotentorial meningiomas and those with origin in the velum interpositum. Neoplasia arising from the falcotentorial junction occur where the dural folds of the tentorium meet with the cerebral falx, and can project antero-superiorly, inferiorly or posteriorly. Meningiomas (rarer) of the velum interpositum occupy the pineal region and have no connection with the dura mater. They originate in the posterior portion of this structure, formed by two layers of pia mater, which constitute the floor of the third ventricle and contains the internal cerebral veins and their tributaries and medial posterior choroidal arteries. ${ }^{2}$ In this case, the meningioma had no dural attachment, which leads to the diagnosis of velum interpositum meningioma.

The main symptoms presented by patients with pineal region meningiomas are related to intracranial hypertension and hydrocephaly, such as headache, gait difficulties, visual disturbances, papilledema, dizziness and cognitive impairments, which stem from obstructed CSF (cerebrospinal fluid) drainage; in the event of aqueduct obstruction, symptoms can develop rapidly. ${ }^{7}$ Parinaud syndrome (paralysis of vertical gaze, convergence-retraction nystagmus, abnormal pupils with unreactive photomotor reflex) is described in up to $10 \%$ of the cases of pineal region meningioma; changes in extrinsic ocular movement are rare in meningiomas of the pineal region, aiding their differentiation from other tumors of this area for which these findings are more common. ${ }^{2}$ Other presentations described include hemifacial spasm, hypoacusis and early puberty. ${ }^{5,7,8}$ In the present case, the time elapsed between symptom onset and diagnosis was similar to the period reported in the literature. ${ }^{2}$

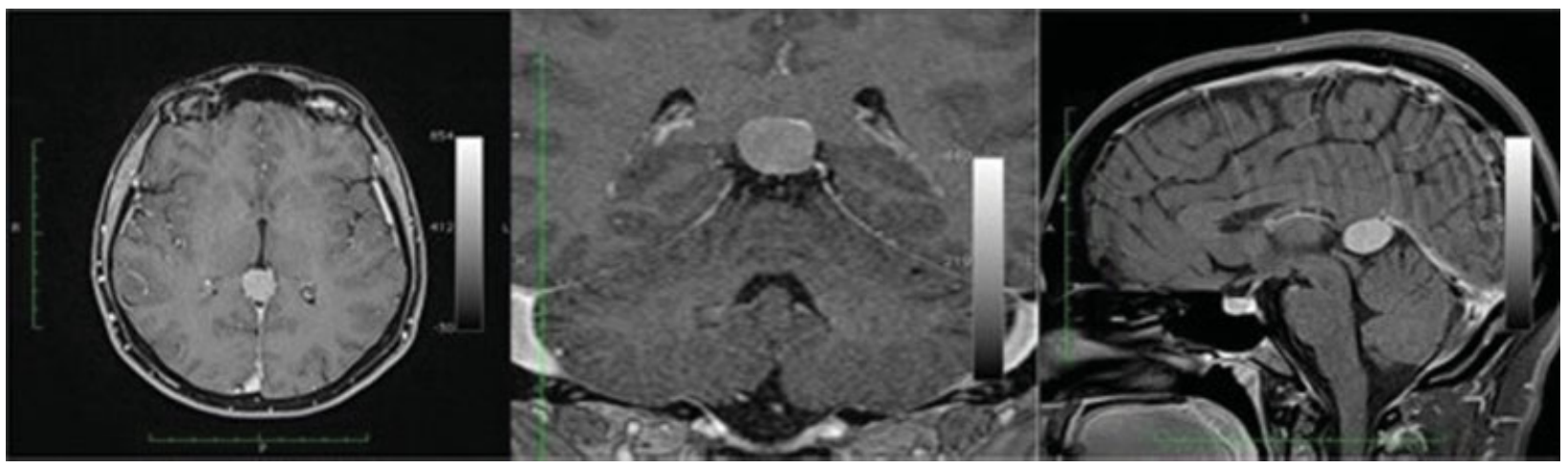

Fig. 1 6-month follow up head magnetic resonance imaging scan, T1-weighted post-contrast, axial (A), coronal (B) and sagittal (C) views, disclosing extra-axial lesion with intense homogeneous paramagnetic agent uptake. 
Despite advances in diagnostic imaging techniques, differentiating between meningioma and other tumors of the pineal region remains a challenge. ${ }^{7}$ However, neuroimaging can help to distinguish malignant from benign lesions and also primitive pineal lesions from tumors with origins in the surrounding structures. ${ }^{4}$ Germinomas can be seen on cranial computed tomography (CT) as circumscribed expansive, hyperattenuating lesions of the pineal region, due to the high lymphocyte content of the tumor, and typically envelop the gland; on MRI, they can have cystic components within the tumor lesion and are iso- and hyperintense in relation to gray matter on T1 and T2-weighted images, showing less diffusion owing to their hypercellular nature. ${ }^{4,9}$ On axial views post-contrast, germinomas exhibit a characteristic "butterfly" shape. ${ }^{4}$

Pineocytomas are generally less than $3 \mathrm{~cm}$ in diameter and therefore have a low mass effect, "exploded" calcifications toward the periphery, and a cystic center. ${ }^{4,9}$ These tumors are characterized by a homogenous, isointense signal on T1 and hyperintense signal on T2-weighted MRI. ${ }^{4}$

Meningiomas typically have avid contrast uptake and tend to be seen separate from the pineal gland, raising the mesencephalic tectum; they tend to have homogeneous contrast uptake on T1 and present as extra-axial lesions on MRI, ${ }^{9}$ as seen in the images of the present case.

The management of pineal region tumors is generally according to a series of questions that need to be defined, ${ }^{5}$ including: whether the origin of the tumor is in the pineal gland or surrounding regions; whether the tumor is localized or disseminated; the possibility of reaching diagnosis without histological confirmation; and finally, the need for surgical intervention, and if so, the indication for biopsy or excision.

Germinomas tend to secrete markers in the CSF or blood and, in cases in which these are detected, histological confirmation is not obligatory, and adjuvant therapy can be employed immediately. Pure germinomas are tumors with an excellent prognosis, and the current approach entails chemotherapy followed by radiotherapy with field extended to the ventricles. ${ }^{5}$ Pineocytomas are the most highly differentiated pineal parenchymal tumors and should be completely removed whenever possible. Pineoblastomas are not highly differentiated and can be managed by surgery and adjuvant chemo-radiotherapy, having a variable prognosis depending on the age of the patient. ${ }^{5}$ Meningiomas are managed surgically and their resectability depends on the degree of adherence to surrounding vascular structures, notably the Galenic venous system and anterior part of the straight sinus. ${ }^{7}$ The best approach to the pineal region (transtentorial or infratentorial supracerebellar) remains a matter of debate in the literature, ${ }^{2,7}$ but preservation of the vascular structures (internal and basal cerebral veins, Galen veins, for instance) is more important than complete removal of the tumor. ${ }^{2}$ In the present case, the Galen system was pushed downwardly, thus, the transtentorial route was elected.

\section{Conclusion}

Pineal region meningiomas are rare lesions. Given the nonspecific characteristics of these lesions on imaging exams, they should be considered as a differential diagnosis of expansive lesions in this region.

\section{Conflicts of Interest}

The authors declare that there are no conflicts of interest.

\section{References}

1 Mottolese C, Szathmari A, Beuriat PA. Incidence of pineal tumours. A review of the literature. Neurochirurgie 2015;61(23):65-69. Doi: 10.1016/j.neuchi.2014.01.005

2 Nowak A, Dziedzic T, Czernicki T, Kunert P, Marchel A. Falcotentorial and velum interpositum meningiomas: two distinct entities of the pineal region. Neurol Neurochir Pol 2014;48(06):397-402. Doi: 10.1016/j.pjnns.2014.09.009

3 Ahmed AI, Zaben MJ, Mathad NV, Sparrow OCE. Endoscopic biopsy and third ventriculostomy for the management of pineal region tumors. World Neurosurg 2015;83(04):543-547. Doi: 10.1016/j.wneu.2014.11.013

4 Deiana G, Mottolese C, Hermier M, Louis-Tisserand G, Berthezene Y. Imagery of pineal tumors. Neurochirurgie 2015;61(23):113-122. Doi: 10.1016/j.neuchi.2014.10.111

5 Frappaz D, Conter CF, Szathmari A, Valsijevic A, Mottolese C. The management of pineal tumors as a model for a multidisciplinary approach in neuro-oncology. Neurochirurgie 2015;61(23):208-211. Doi: 10.1016/j.neuchi.2014.03.003

6 Blakeley JO, Grossman SA. Management of pineal region tumors. Curr Treat Options Oncol 2006;7(06):505-516. Doi: 10.1007/ s11864-006-0025-6

7 Matushita H, Pinto FC, Plese JP. Meningiomas of pineal region in children. Arq Neuropsiquiatr 2007;65(4A):1000-1006. Doi: $10.1590 /$ S0004-282 × 2007000600017

8 Mallucci CL, Obukhov S. Successful removal of large pineal region meningiomas: two case reports. Surg Neurol 1995;44(06): 562-566. Doi: 10.1016/0090-3019(95)00220-0

9 Hallinan JT, Hegde AN, Lim WE. Dilemmas and diagnostic difficulties in meningioma. Clin Radiol 2013;68(08):837-844. Doi: 10.1016/j.crad.2013.03.007 